\title{
Quantitative computed tomography analysis of emphysema severity and distribution in chronic obstructive lung disease, correlation with clinical findings
}

\author{
Eranıl ASLAN ${ }^{1}(I D)$ \\ Furkan KAYA ${ }^{\mathbf{1}}$ (ID) \\ Esra ÖZGÜL ${ }^{1}(I D)$ \\ Aydın $\mathrm{BALCl}^{2}(\mathrm{ID})$ \\ Emin DEMIREL $^{1}$ (ID) \\ Ersin GÜNAY ${ }^{3}$ (ID)
}

${ }^{1}$ Department of Radiology, Afyonkarahisar Health Sciences University Faculty of Medicine, Afyonkarahisar, Turkey

${ }^{1}$ Afyonkarahisar Sağlık Bilimleri Üniversitesi Tıp Fakültesi, Radyoloji Anabilim Dalı, Afyonkarahisar, Türkiye

2 Department of Chest Diseases, Afyonkarahisar Health Sciences University Faculty of Medicine, Afyonkarahisar, Turkey

${ }^{2}$ Afyonkarahisar Sağlık Bilimleri Üniversitesi Tıp Fakültesi, Göğüs Hastalıkları Anabilim Dalı, Afyonkarahisar, Türkiye

${ }^{3}$ Department of Chest Diseases, Yuksek Ihtisas University School of Medicine, Ankara, Turkey

3 Yüksek Ihtisas Üniversitesi Tıp Fakültesi, Göğüs Hastalıkları Anabilim Dalı, Ankara, Türkiye
Cite this article as: Aslan E, Kaya F, Özgül E, Balcı A, Demirel E, Günay E. Quantitative computed tomography analysis of emphysema severity and distribution in chronic obstructive lung disease, correlation with clinical findings. Tuberk Toraks 2021;69(3):338-348.

\section{Yazıșma Adresi (Address for Correspondence)}

\section{Dr. Furkan KAYA}

Department of Radiology, Afyonkarahisar Health Sciences University Faculty of Medicine AFYONKARAHISAR - TURKEY

e-mail: furkaya157@hotmail.com

OCopyright 2021 by Tuberculosis and Thorax.

Available on-line at www.tuberktoraks.org.com

\section{ABSTRACT}

Quantitative computed tomography analysis of emphysema severity and distribution in chronic obstructive lung disease, correlation with clinical findings

Introduction: This study aimed to evaluate the correlation between different densitometric parameters on chest computed tomography (CT) and pulmonary function tests (PFT) of patients with emphysema-predominant chronic obstructive pulmonary disease (COPD).

Materials and Methods: A retrospective evaluation was made of 56 patients with COPD. The lungs were segmented into nine sections. Normal and emphysematous parenchyma were measured using low attenuation area percentage $(\% L A A)$, percentile density $(P D)$, and mean lung density (MLD) parameters. The effects of emphysema distribution on PFT were evaluated using $\% L A A, P D, M L D$, kurtosis and skewness methods.

Results: Fifty-six patients, all diagnosed with COPD, were evaluated. The $\%$ LAA-910 method showed significant correlation with forced expiratory volume in one second $\left(F E V_{1}\right)$ compared to other densitometric parameters ( $p=<0.001, r=-0.556)$. Other densitometric parameters differed between segments in terms of sensitivity for $F E V_{1}$. It was determined that right lung mid-zone segment involvement affected $F E V$, more than other segments when the \%LAA -910 method was used ( $p=<0.001, r=-0.569) . \%$ LAA -950 had the largest area under the curve in ROC curve analysis and was determined 
to have $2.2 \%$ diagnostic property for predicting Global Initiative for Obstructive Lung Disease (GOLD) AB-CD staging (sensitivity $81 \%$, specificity $74 \%)$.

Conclusion: Quantitative analysis is an objective method for determining the distribution and severity of emphysema. There was a significant correlation between densitometry and PFT values. Quantitative analysis may be considered suitable for use in evaluating the severity of emphysema and predicting the clinical findings of patients.

Key words: Emphysema; densitometry; pulmonary function test

\section{ÖZ}

Kronik obstrüktif akciğer hastalığında bilgisayarlı tomografide amfizem miktarı ve dağılımının kantitatif yöntemlerle değerlendirilmesi ve klinik bulguları ile korelasyonu

Giriş: Çalışmamızda amfizem predominant tip kronik obstrüktif akciğer hastalı̆̆ı (KOAH) olan hastaların toraks bilgisayarlı tomografi (BT) tetkiklerinde farklı kantitatif parametreleri kullanarak solunum fonksiyon testi ile korelasyonunu arasındaki ilişkiyi değerlendirmeyi amaçladık.

Materyal ve Metod: Çalışmamız retrospektif olarak gerçekleştirildi. Çalışmaya KOAH tanısı olan 56 hastası dahil edildi. Toraks BT görüntüleri dokuz bölgeye segmente edildi. Ayrılan zonlarda normal parankim ve amfizem alanların vokselleri kantitatif ölçümler ile düşük atenüasyonlu alan yüzdesi (\%LAA), persentil dansite değeri (PD), ortalama akciğer dansitesi (MLD) olarak ölçüldü. \%LAA metodunda farklı Hounsfield Unit (HU) değerlerinin duyarlılığını belirlemek için -950 HU, -925 HU, -910 HU eşik değerleri kullanıldı. PD metodunda farklı eşik değerlerinin duyarııı̆ını belirlemek için PD 10 ve PD 15 eşik değerleri kullanıldı. Hastaların histogram analizi yapılarak skewness ve kurtosis değerleri ölçüldü. Kantitatif parametrelerden \%LAA, PD, MLD, kurtosis ve skewness değerleri kullanılarak hastanın amfizemin dă̆ılımının SFT üzerine etkisi araştırıldı. Tüm akciğer \%LAA -950, \%LAA -925, \%LAA -910, persentil 10, persentil 15 ve MLD değerlerinin GOLD ABCD evrelemesini öngörmede tanısal karar verdirici özellikleri ROC eğrisi analiziyle incelendi.

Bulgular: Tüm segmentler değerlendirildiğinde dansitometrik değerlerden LAA\% -910 diğer parametrelere kıyasla zorlu ekspirasyonun birinci saniyesinde atılan volümü $\left(F E V_{1}\right)$ ile daha yüksek korelasyon gösterdi $(p=<0,001, r=-0,556)$. LAA\% -910 metodunda, sağ akciğer orta zon segmentinin tutulumunun FEV 1 değerini diğer segmentlere kryasla daha çok etkilemektedir ( $p=<0,001$, $r=-0,569)$. GOLD ABCD evrelemesini öngörmede tanısal karar verdirici özellikleri ROC eğrisi analizinde eğri altı alan en büyük olan $\%$ LAA -950 için \%2,20 (duyarlılık \%81, özgüllük \%74) olarak bulundu.

Sonuç: Toraks BT kantitatif analizler amfizem yaygınlığını ve şiddetini belirlemede objektif sonuçlar vermektedir. Kantitatif bilgisayarlı Tomoagrafi analizi ile SFT değerleri arasında anlamlı korelasyon mevcuttur. Kantitatif analizlerin amfizem şiddetini değerlendirmede ve hastanın mevcut klinik bulgularını öngörmede kullanılabileceğini düşünmekteyiz.

Anahtar kelimeler: Amfizem; dansitometri; solunum fonksiyon testi

\section{INTRODUCTION}

Chronic obstructive pulmonary disease (COPD) is a disease with systemic effects that develops as a result of inflammation formed against various gases and particles, primarily cigarette smoke, and is characterized by progressive airflow restriction (1). Classification of COPD cases on computed tomography (CT) by phenotype (emphysema predominant, airway predominant, or mixed type) is based on the morphological appearance of pathological changes associated with restricted airflow. Bronchial wall thickening with little or no emphysema called airway predominant type and the presence of emphysema without bronchial wall thickening is named emphysema predominant type. Both bronchial wall thickening and the presence of emphysema is classified as mixed type $(2,3)$.

Lung densitometry is based on measuring the amount of $\mathrm{X}$-ray attenuation of pulmonary tissue using various software programs. In the obtained lung parenchyma, the HU values of each voxel are measured and analyzes providing information about the lung density are performed using different methods. Mean lung density (MLD) is the average of the densities of all the voxels of the lung parenchyma (4). The Relative Area (RA)/Low Attenuation Area Percentage (\%LAA) is the ratio of all voxels in the relevant area to the number of voxels with a value below the specified threshold $\mathrm{HU}$ value. The most common threshold HU values used to quantitatively measure the amount of emphysema are -950, -925, and -910. In the distribution of $\mathrm{HU}$ values of voxels in the segment examined in the Percentile Index (Perc)/Percentile Density (PD) method, the $\mathrm{HU}$ value remains below the selected threshold percentile. When the amount of emphysema increases in the lungs, the density histogram shifts to lower $\mathrm{HU}$ values and this causes a decrease in the Percentile Index (5). 
Perc10 (PD 10\%) and Perc15 (PD 15\%) are the two most commonly used indices in emphysema. PD15 is less affected by image noise than PD10 (6) .

Skewness defines the degree of asymmetry of the curve in the histogram. Kurtosis defines the degree of sharpness or flatness of the curve (7).

The aim of this study was to evaluate the relationship between pulmonary test functions and clinical findings using quantitative computed tomography (QCT) analysis of chest CT examinations with different densitometric parameters in patients with emphysema-dominant COPD.

\section{MATERIALS and METHODS}

\section{Patient Selection}

This retrospective study included a total of 56 COPD patients. Anthropometric measurements, smoking habits and routine examination findings were recorded. The study group consisted of patients with emphysematous changes on chest $\mathrm{CT}$ and no signs of fibrosis and obstruction in pulmonary function tests (PFT). A total of 2591 patients who underwent routine chest CT and PFT in the last year, with a period of less than two months between examinations were identified. The 56 patients included in the study had emphysema-dominant pattern on chest $\mathrm{CT}$ and changes related to small airway disease in PFT (Figure 1).

\section{Computed Tomography Technique}

Images were acquired on Toshiba Aquilion Prime (80x2) multislice CT device. Non-contrast images were taken during deep inspirium from the apexes to adrenal glands with $2 \mathrm{~mm}$ consecutive slice thickness, using tube voltage $120 \mathrm{kV}$, collimation $0.5 \times 80$ $\mathrm{mm}$, image area $370 \mathrm{~mm}$, matrix $512 \times 512$, rotation speed 0.35 secs, table level $15 \mathrm{~mm} / \mathrm{sec}$, pitch factor 0.813 and helical pitch 65.0. Scanning time was 2-4 seconds. Soft reconstruction (B30F) was used.

\section{Pulmonary Function Test (PFT)}

The PFTs were applied to patients using a ZAN GPI.3.00 device (ZAN nSpire Health $\mathrm{GmbH}$, Germany) in spirometry mode. The pre-bronchodilator spirometry test was applied. The bronchodilator drug of Salbutamol was used as four separate 100 mcg inhalations at $30 \mathrm{sec}$ intervals for a total dose of $400 \mathrm{mcg}$ applied with an inhaler. Patients with an increase of $>200 \mathrm{ml}$ and $>12 \%$ in $\mathrm{FEV}_{1}$ and/or FVC compared to baseline were evaluated as early reversibility positive. Postbronchodilator $\mathrm{FEV}_{1} / \mathrm{FVC}$ of $<70 \%$ was interpreted as airway obstruction. The predicted $\mathrm{FEV}_{1}$, FVC, FEV/FVC were calculated.

\section{GOLD Staging}

Patients with airway obstruction were graded from 1 to 4 according to the GOLD 2018 guidelines (8).

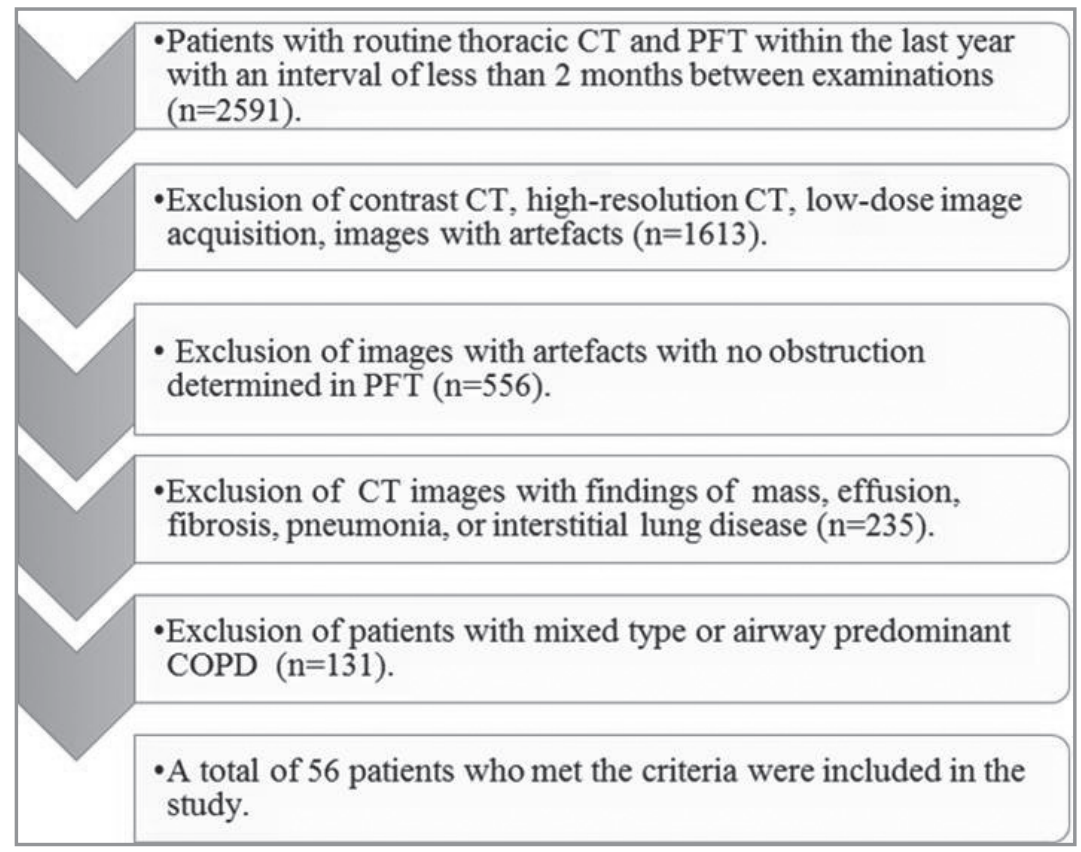

Figure 1. Flow diagram of the patient selection. 
Patients with $\mathrm{FEV}_{1} \geq 80 \%$ were classified as GOLD 1, $\mathrm{FEV}_{1}<80 \%$ and $\geq 50 \%$ as GOLD $2, \mathrm{FEV}_{1}<50 \%$ and $\geq 30 \%$ as GOLD 3, and $\mathrm{FEV}_{1}<30 \%$ as GOLD 4 . Patients were also staged as A-B-C-D according to the GOLD 2018 guidelines. According to this classification, GOLD A: low risk patients with few symptoms, 0-1 exacerbation per year, and Modified Medical Research Council dyspnea scale (mMRC) 0-1 score or COPD Assessment Test (CAT) score> 10; GOLD B: low risk patients with more symptoms, $0-1$ exacerbation per year, and $\mathrm{mMRC} \geq 2$ score or CAT score $\geq 10$; GOLD C: high risk patients with few symptoms, $\geq 2$ exacerbations per year, and mMRC 0-1 score or CAT score > 10; GOLD D: high risk patients with more symptoms, $\geq 2$ exacerbations per year, and $\mathrm{mMRC} \geq 2$ score or CAT score $\geq 10$.

\section{Quantitative Computed Tomography Analysis (QCT)}

The images of the patients were recorded in DICOM format and were transferred to the Chest Imaging Platform (CIP) extension of the open access 3D Slicer (http://www.slicer.org version: 4.10.2) (9) software for quantitative measurements. Only the lung parenchy- ma was included in the densitometric examination. The program automatically removed large airways, hilar main vascular structures, mediastinum and costa. The parenchyma of the whole lungs, right lung and left lung were evaluated densitometrically. In addition, the program automatically separated each lung into three equal volumes of upper, mid and lower zones. Following lung parenchyma segmentation, voxel analysis was made separately of the nine regions. To evaluate the correlation of threshold HU values with spirometry, three different $\mathrm{LAA} \%$ values were used of $-950 \mathrm{HU},-925 \mathrm{HU}$, and $-910 \mathrm{HU}$. Skewness and kurtosis values of the histogram curve were calculated. In the percentile density method, PD10 and PD15 values in the nine regions were used and the mean lung density of each region was measured (Figure 2).

\section{Statistical Analysis}

Data obtained in the study were analyzed statistically using SPSS vn. 21.0 software. Conformity of continuous variables to normal distribution was assessed with visual (histogram and probability graphs) and
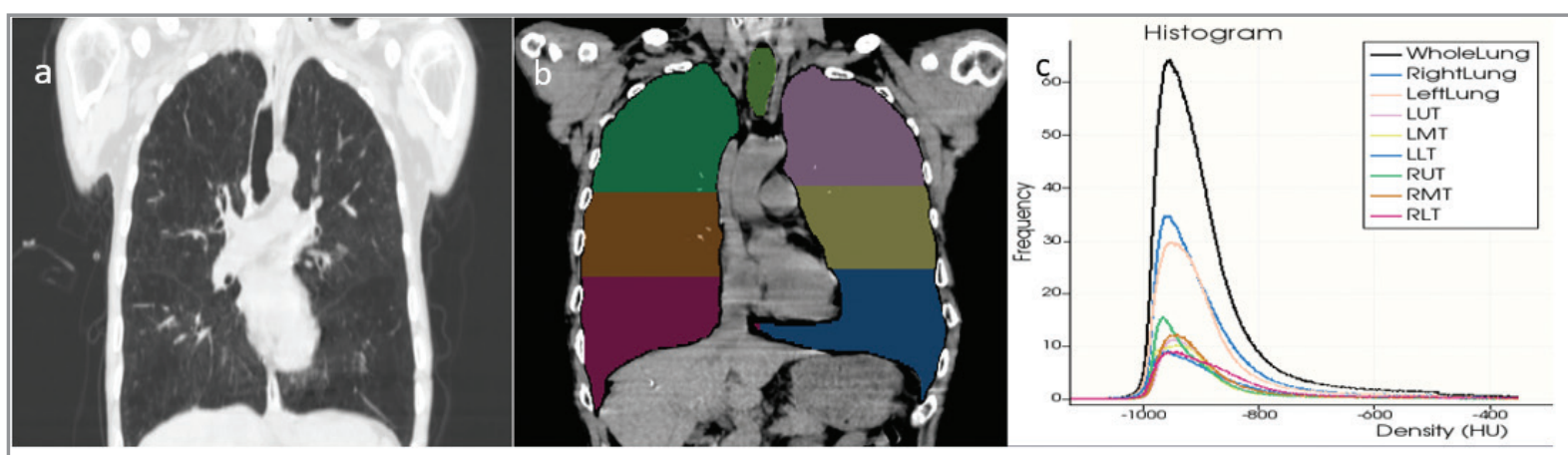

d

\begin{tabular}{|c|c|c|c|c|c|c|}
\hline Region & LAA $\%-950$ & LAA \%-925 & LAA $\%-910$ & Perc10 & Perc15 & Mean \\
\hline WholeLung & 28.269 & 46.156 & 55.456 & -975.000 & -968.000 & -880.283 \\
\hline Rightlung & 28.433 & 46.139 & 55.054 & -974.000 & -967.000 & -881.560 \\
\hline RUT & 37.620 & 56.056 & 64.395 & -978.000 & -973.000 & -899.601 \\
\hline RMT & 25.135 & 45.262 & 55.733 & -970.000 & -963.000 & -879.154 \\
\hline RLT & 22.645 & 37.237 & 45.178 & -972.000 & -963.000 & -866.166 \\
\hline Leftlung & 28.089 & 46.175 & 55.897 & -976.000 & -968.000 & -878.882 \\
\hline LUT & 24.738 & 45.644 & 56.664 & -969.000 & -962.000 & -887.945 \\
\hline LMT & 30.394 & 49.236 & 59.652 & -979.000 & -971.000 & -879.112 \\
\hline LLT & 29.031 & 43.663 & 51.456 & -980.000 & -972.000 & -869.955 \\
\hline
\end{tabular}

Figure 2. a. Non-contrast coronal chest CT in parenchyma window of a 55-year old male patient, $\mathbf{b}$. segmentation into regions of the lung parenchyma, c. histogram analysis of the whole lung, d. quantitative analysis results of the \%LAA -950, \%LAA -925, \%LAA -910, PD15, PD10, MLD parameters of the nine regions (\%LAA: Low attenuation area percentage, PD: Percentile density, MLD: Mean lung density). 
analytical methods (Kolmogorov-Smirnov, ShapiroWilk tests). For descriptive statistics, data conforming to normal distribution were stated as mean \pm standard deviation values and those not showing normal distribution as median, minimum and maximum values. Correlations of continuous variables with parametric properties were investigated with the Pearson test and for those not with parametric properties, the Spearman test was used. A value of $p<$ 0.05 was accepted as statistically significant.

\section{RESULTS}

\section{Study Population}

Evaluation was made of 56 patients diagnosed with COPD, comprising 47 males and nine females with a mean age of $63.43 \pm 8.48$ years, mean height of $167.46 \pm 7.88 \mathrm{~cm}$, mean weight of $76.39 \pm 12.57 \mathrm{~kg}$, mean body mass index of $27.45 \pm 4.97$, and mean smoking duration of $47.16 \pm 24.49$ packet years. A total of 49 of the 56 patients were active smokers and there were no ex-smokers. Staging was GOLD A in $13(23.2 \%)$ patients, GOLD B in $10(17.9 \%)$, GOLD $\mathrm{C}$ in 15 (26.8\%), and GOLD D in 18 (32.1\%).

\section{The Correlation of Quantitative CT Analysis and the Clinical Findings}

Evaluation was made of the \%LAA -950, \%LAA -925, \%LAA -910, PD10, PD15, MLD, kurtosis, and skewness values of the nine regions (Table 1).

In all regions, a statistically significant negative correlation was determined between \%LAA -950, \%LAA -925, \%LAA -910 and FEV 1 . A statistically significant positive correlation was determined between PD10, PD15, MLD and $\mathrm{FEV}_{1}$ in all the regions. $\mathrm{FEV}_{1}$ was seen to be more strongly correlated with \%LAA -910 , than with \%LAA -950 and \%LAA -925 ( $p<0.001$, $r=-0.471$ ).

In eight of the lung regions, PD15 was seen to be more strongly correlated with $\mathrm{FEV}_{1}$ than PD10. In all the regions, \%LAA -910 was more correlated with FEV $_{1}$ than PD15, \%LAA -925 and \%LAA -910 were seen to be more correlated with $\mathrm{FEV}_{1}$ than PD10 and PD15, and \%LAA -950 was seen to be less correlated with $\mathrm{FEV}_{1}$ than PD10 and PD15. In all the regions, no statistically significant correlation was determined between kurtosis and skewness values and $\mathrm{FEV}_{1}$, FVC and $\mathrm{FEV}_{1} /$ FVC (Table 2).

The \%LAA -950, \%LAA -925, \%LAA -910, PD10, PD15, and MLD values were examined in the whole lung of the patients according to the GOLD 1-4 staging. All the values were determined to be higher in GOLD 3 and 4 compared to GOLD 1 and 2 ( $p<$ 0.001) (Table 3).

In the evaluations of the correlations between the whole lung QCT parameters and sociodemographic variables, weight showed the highest correlation with $\%$ LAA-950 ( $p<0.001, r=-0.536)$. The highest correlation of body mass index (BMI) was seen with PD10 ( $p<0.001, r=0.626)$. The highest correlation of smoking was seen with PD15 $(p<0.001, r=-0.470)$ (Table 4).

\section{The Role of QCT Analysis in Determining Severity According to the GOLD Classification}

The diagnostic value of the whole lung QCT parameters in the prediction of GOLD ABCD staging was examined with ROC analysis. The diagnostic value of the whole lung \%LAA -950, \%LAA -925, \%LAA -910, PD10 and PD15 values was seen to be statisti-

Table 1. Evaluation of the whole lung \%LAA-950, \%LAA-925, \%LAA-910, PD10, PD15, MLD, kurtosis and skewness results

\begin{tabular}{|lcc|} 
Whole Lung Densitometry Values & Mean $(+$ Standard Deviation) & Median $($ Min-Max) \\
\hline \%LAA -950 & $9.10(+10.57)$ & $5.06(.00-37.86)$ \\
\%LAA -925 & $18.70(+16.12)$ & $14.13(.01-57.97)$ \\
\%LAA -910 & $26.45(+19.46)$ & $27.00(.07-67.65)$ \\
PD10 (HU) & $-930.95(+37.34)$ & $-933.00(-995.00)-(-853.00)$ \\
PD15 (HU) & $-921.23(+37.67)$ & $-924.00(-983.00)-(-839.00)$ \\
MLD (HU) & $-823.86(+42.65)$ & $-830.29(-904.28)-(-717.52)$ \\
Kurtosis & $14.20(+5.12)$ & $14.01(3.56-24.16)$ \\
Skewness & $3.33(+0.61)$ & $3.35(1.83-4.47)$ \\
\hline
\end{tabular}

Min: Minimum value, Max: Maximum value, \%LAA: Low attenuation area percentage, PD: Percentile density -Density value corresponding to the threshold percentage value, MLD: Mean lung density. 
Aslan E, Kaya F, Özgül E, Balcı A, Demirel E, Günay E.

Table 2. Evaluation of the correlation of $\mathrm{FEV}_{1}$ with the \%LAA - 950, \%LAA - 925, \%LAA - 910, PD10, PD15, and MLD values of all the segments of the lungs

\begin{tabular}{|c|c|c|}
\hline & $\mathbf{r}$ & $\mathbf{p}$ \\
\hline Whole lung \%LAA -950 & $-0.471^{* *}$ & $<0.001$ \\
\hline Whole lung \%LAA -925 & $-0.552^{* *}$ & $<0.001$ \\
\hline Whole lung \%LAA -910 & $-0.556^{* *}$ & $<0.001$ \\
\hline Whole lung PD10 & $0.502^{* *}$ & $<0.001$ \\
\hline Whole lung PD15 & $0.520^{* *}$ & $<0.001$ \\
\hline Whole lung MLD & $0.413^{* *}$ & 0.002 \\
\hline Right lung \%LAA -950 & $-0.461^{* *}$ & $<0.001$ \\
\hline Right lung \%LAA -925 & $-0.535^{* *}$ & $<0.001$ \\
\hline Right lung \%LAA -910 & $-0.539 * *$ & $<0.001$ \\
\hline Right lung PD10 & $0.493^{* *}$ & $<0.001$ \\
\hline Right lung PD15 & $0.517^{* *}$ & $<0.001$ \\
\hline Right lung MLD & $0.411^{* *}$ & 0.002 \\
\hline Left lung \%LAA -950 & $-0.448^{* *}$ & 0.001 \\
\hline Left lung \%LAA -925 & $-0.545^{* *}$ & $<0.001$ \\
\hline Left lung \%LAA -910 & $-0.553^{* *}$ & $<0.001$ \\
\hline Left lung PD10 & $0.483^{* *}$ & $<0.001$ \\
\hline Left lung PD15 & $0.495^{* *}$ & $<0.001$ \\
\hline Left lung MLD & $0.388^{* *}$ & 0.003 \\
\hline Left lung upper zone \%LAA -950 & $-0.324^{*}$ & 0.015 \\
\hline Left lung upper zone \%LAA -925 & $-0.423^{* *}$ & 0.001 \\
\hline Left lung upper zone \%LAA -910 & $-0.446^{* *}$ & 0.001 \\
\hline Left lung upper zone PD10 & $0.395^{* *}$ & 0.003 \\
\hline Left lung upper zone PD15 & $0.408^{* *}$ & 0.002 \\
\hline Left lung upper zone MLD & $0.372^{* *}$ & 0.005 \\
\hline Left lung mid zone \%LAA -950 & $-0.424^{* *}$ & 0.001 \\
\hline Left lung mid zone\%LAA -925 & $-0.531^{* *}$ & $<0.001$ \\
\hline Left lung mid zone \%LAA -910 & $-0.551 * *$ & $<0.001$ \\
\hline Left lung mid zone PD10 & $0.497^{* *}$ & $<0.001$ \\
\hline Left lung mid zone PD15 & $0.503^{* *}$ & $<0.001$ \\
\hline Left lung mid zone MLD & $0.381^{* *}$ & 0.004 \\
\hline Left lung lower zone \%LAA -950 & $-0.485^{* *}$ & $<0.001$ \\
\hline Left lung lower zone \%LAA -925 & $-0.541 * *$ & $<0.001$ \\
\hline Left lung lower zone \%LAA -910 & $-0.542^{* *}$ & $<0.001$ \\
\hline Left lung lower zone PD10 & $0.502^{* *}$ & $<0.001$ \\
\hline Left lung lower zone PD15 & $0.505^{* *}$ & $<0.001$ \\
\hline Left lung lower zone MLD & $0.355^{* *}$ & 0.007 \\
\hline Right lung upper zone \%LAA -950 & $-0.337^{*}$ & 0.011 \\
\hline Right lung upper zone \%LAA -925 & $-0.396 * *$ & 0.003 \\
\hline Right lung upper zone \%LAA -910 & $-0.418^{* *}$ & 0.001 \\
\hline Right lung upper zone PD10 & $0.399 * *$ & 0.002 \\
\hline Right lung upper zone PD15 & $0.417^{* *}$ & 0.001 \\
\hline
\end{tabular}


Table 2. Evaluation of the correlation of $\mathrm{FEV}_{1}$ with the \%LAA - 950, \%LAA - 925, \%LAA - 910, PD10, PD15, and MLD values of all the segments of the lungs (continue)

\begin{tabular}{|lcc|}
\hline & $\mathbf{r}$ & $\mathbf{p}$ \\
\hline Right lung upper zone MLD & $0.388^{* *}$ & 0.003 \\
Right lung mid zone \%LAA -950 & $-0.459^{* *}$ & $<0.001$ \\
Right lung mid zone \%LAA -925 & $-0.554^{* *}$ & $<0.001$ \\
Right lung mid zone \%LAA -910 & $-0.569^{* *}$ & $<0.001$ \\
Right lung mid zone PD10 & $0.504^{* *}$ & $<0.001$ \\
Right lung mid zone PD15 & $0.524^{* *}$ & $<0.001$ \\
Right lung mid zone MLD & $0.405^{* *}$ & 0.002 \\
Right lung lower zone \%LAA -950 & $-0.428^{* *}$ & 0.001 \\
Right lung lower zone \%LAA -925 & $-0.505^{* *}$ & $<0.001$ \\
Right lung lower zone \%LAA -910 & $-0.506^{* *}$ & $<0.001$ \\
Right lung lower zone PD10 & $0.494^{* *}$ & $<0.001$ \\
Right lung lower zone PD15 & $0.491^{* *}$ & $<0.001$ \\
Right lung lower zone MLD & $0.351^{* *}$ & 0.008 \\
\hline \%LAA: Low attenuation area percentage, PD: Percentile density -Density value corresponding to the threshold percentage value, MLD: Mean lung \\
density. \\
*p< 0.05 statistically significant. \\
**p $<0.01$ statistically significant. & & \\
\hline
\end{tabular}

Table 3. Evaluation of GOLD 1-2 and GOLD 3-4 stage patients in respect of \%LAA -950, \%LAA -925, \%LAA -910, PD10, PD15 and MLD

\begin{tabular}{ccc} 
& FEV $_{\mathbf{1}}$ & \\
\hline GOLD 1-2 $(\mathbf{n}=\mathbf{3 1})$ & GOLD 3-4 $(\mathbf{n}=\mathbf{2 5})$ & $\mathrm{p}$ \\
Mean (+Standard Deviation) & Mean (+Standard Deviation) & $<0.001$ \\
\hline $5.21(+8.24)$ & $13.92( \pm 11.29)$ & $<0.001$ \\
$11.78(+13.26)$ & $27.27( \pm 15.40)$ & $<0.001$ \\
$18.26(+17.30)$ & $36.60( \pm 17.30)$ & $<0.001$ \\
$-915.94(+37.18)$ & $-949.56( \pm 28.55)$ & $<0.001$ \\
$-905.48(+36.67)$ & $-940.76( \pm 29.22)$ & 0.010 \\
$-811.32(+43.30)$ & $-839.42( \pm 37.02)$ &
\end{tabular}

$\mathrm{p}<0.05$ statistically significant.

Min: Minimum value, Max: Maximum value, \%LAA: Low attenuation area percentage, PD: Percentile density

-Density value corresponding to the threshold percentage value, MLD: Mean lung density

cally significant. Of the densitometric parameters in this study, the method with the greatest area under the curve was \%LAA -950. When the GOLD CD group corresponding to the disease was selected, the whole lung threshold value was 2.20 for \%LAA -950 (sensitivity $81 \%$, specificity $74 \%$ ), 8.61 for \%LAA -925 (sensitivity $78 \%$, specificity $61 \%$ ), and 24.2 for $\%$ LAA -910 (sensitivity $61 \%$, specificity $61 \%$ ). As the value of the $P D$ method were negative below zero, when the GOLD AB group corresponding to the disease was selected in the analysis, the threshold values were -931 HU for PD10 (sensitivity 70\%, specificity $70 \%$ ), and -931 HU for PD15 (sensitivity 82\%, specificity $64 \%$ ) (Table 5).

\section{DISCUSSION}

Chest CT is currently used in the evaluation and scoring of the severity of destruction of the whole lung parenchyma (5). Since semi-quantitative methods give subjective results, it is recommended to use quantitative methods in chest CT emphysema scoring for quantitative evaluation of emphysema (10). 
Table 4. Evaluation of the correlation between sociodemographic variables and the whole lung \%LAA -950, \%LAA -925, \%LAA -910, PD10, PD15, and MLD values

\begin{tabular}{|c|c|c|c|c|c|c|c|}
\hline & & $\begin{array}{l}\text { Whole Lung } \\
\% \text { LAA -950 }\end{array}$ & $\begin{array}{l}\text { Whole Lung } \\
\text { \% LAA -925 }\end{array}$ & $\begin{array}{l}\text { Whole Lung } \\
\% \text { LAA -910 }\end{array}$ & $\begin{array}{l}\text { Whole Lung } \\
\text { PD10 }\end{array}$ & $\begin{array}{c}\text { Whole Lung } \\
\text { PD15 }\end{array}$ & $\begin{array}{c}\text { Whole Lung } \\
\text { MLD }\end{array}$ \\
\hline \multirow{2}{*}{ Height } & $r$ & 0.197 & $0.271^{*}$ & $0.306^{*}$ & $-0.326^{*}$ & $-0.325^{*}$ & $-0.362^{* *}$ \\
\hline & $p$ & 0.146 & 0.044 & 0.022 & 0.014 & 0.014 & 0.006 \\
\hline \multirow{2}{*}{ Weight } & $r$ & $-0.536^{* *}$ & $-0.509 * *$ & $-0.465^{* *}$ & $0.504^{* *}$ & $0.499 * *$ & $0.316^{*}$ \\
\hline & $p$ & $<0.001$ & $<0.001$ & $<0.001$ & $<0.001$ & $<0.001$ & 0.018 \\
\hline \multirow{2}{*}{ BMI } & $r$ & $-0.583 * *$ & $-0.589 * *$ & $-0.569^{* *}$ & $0.626^{* *}$ & $0.620^{* *}$ & $0.456^{* *}$ \\
\hline & $p$ & $<0.001$ & $<0.001$ & $<0.001$ & $<0.001$ & $<0.001$ & $<0.001$ \\
\hline \multirow{2}{*}{ Age } & $r$ & 0.157 & 0.138 & 0.116 & -0.175 & -0.173 & -0.003 \\
\hline & $p$ & 0.249 & 0.312 & 0.393 & 0.198 & 0.203 & 0.981 \\
\hline \multirow{2}{*}{ Smoking } & $r$ & $0.386^{* *}$ & $0.442^{* *}$ & $0.440^{* *}$ & $-0.464^{* *}$ & $-0.470^{* *}$ & $-0.371^{* *}$ \\
\hline & $p$ & 0.003 & 0.001 & 0.001 & $<0.001$ & $<0.001$ & 0.005 \\
\hline \multicolumn{8}{|c|}{$\begin{array}{l}{ }^{*} p<0.05 \text { statistically significant. } \\
{ }^{* *} p<0.01 \text { statistically significant, } \\
\% \text { LAA: Low attenuation area percentage, PD: Percentile density -Density value corresponding to the threshold percentage value, MLD: Mean lung } \\
\text { density. }\end{array}$} \\
\hline
\end{tabular}

Table 5. The results of the ROC analysis of the diagnostic value of \%LAA -950, \%LAA -925, \%LAA -910, PD10, PD15, MLD methods for the differentiation of GOLD AB and GOLD CD groups

\begin{tabular}{|c|c|c|c|c|}
\hline \multirow[b]{2}{*}{ Whole Lung } & \multirow[b]{2}{*}{ Area Under the Curve } & \multirow[b]{2}{*}{$\mathbf{p}$} & \multicolumn{2}{|c|}{$95 \%$ Confidence Interval } \\
\hline & & & Lower Limit & Upper Limit \\
\hline$\%$ LAA -950 & 0.809 & $<0.001$ & 0.695 & 0.923 \\
\hline \%LAA -925 & 0.785 & $<0.001$ & 0.668 & 0.903 \\
\hline$\%$ LAA -910 & 0.758 & $<0.001$ & 0.632 & 0.883 \\
\hline PD10 & 0.777 & $<0.001$ & 0.654 & 0.899 \\
\hline PD15 & 0.765 & $<0.001$ & 0.642 & 0.889 \\
\hline MLD & 0.631 & 0.097 & 0.485 & 0.777 \\
\hline
\end{tabular}

Although the \%LAA HU method is often used for quantitative measurement of emphysema, no consensus has been reached for the optimal threshold $\mathrm{HU}$ value. Previous studies quantitatively analyzed the preoperative CT images of patients planned to undergo lung surgery to be able to determine the threshold \%LAA HU value showing the highest correlation with microscopic and macroscopic emphysema spread in the lungs and suggested different threshold values (11-13). In the current study, the highest correlation between PFT and the QCT parameters was seen to be with the \%LAA -910 method in all nine regions.

In the current study, a strong correlation was determined between the PD10 and PD15 methods and
$\mathrm{FEV}_{1}$. The \%LAA and PD methods are not independent of each other and have inverse functions in the cumulative histogram curve (14). In this regard, a correlation with PFT can be expected in both methods. Although PD10 and 15 are used frequently, most studies recommend the value of PD $15(7,15,16)$. When the correlation between the PD method and FEV1 was evaluated in the current study, the PD15 correlation was higher than PD10. In the examination of the correlation coefficients of $\mathrm{FEV}_{1}$ with \%LAA-910, \%LAA -925 and PD15, it was seen that the correlation of \%LAA-910 and \%LAA -925 methods was higher than PD15. As the correlation of the \%LAA method with $\mathrm{FEV}_{1}$ was higher in all the segments, it can be considered that the \%LAA method of quantitative measurement of emphysema should be 
used in cross-sectional studies, and the PD method in longitudinal studies.

MLD has been reported to have lower sensitivity than other methods $(17,18)$. MLD method showed the lowest correlation with $\mathrm{FEV}_{1}$ between densitometric parameters. It can be thought that \%LAA and PD methods should be used rather than MLD.

QCT parameter showing the highest correlation with $\mathrm{FEV}_{1}$ was \%LAA -910, and evaluation was made of the correlation of emphysema distribution in both lungs with $\mathrm{FEV}_{1}$. The correlation coefficients of both upper zones were observed to be lower than those of other zones. The reason for this was thought to be that the upper zones of both lungs contributed less to gas exchange. The zones with the highest correlation coefficients were the right lung mid zone and the left lung mid zone, respectively. Chae et al. (19) have reported that right lung lower lobe involvement showed a high correlation with $\mathrm{FEV}_{1}$. It was also found that parenchyma destruction in the lung central section resulted in worse PFT compared to the periphery. In our study, the mid zone included a third of the lower lobe superior and central sections. The results of this study similarly suggested that parenchyma destruction in the right lung mid zone central section was more responsible for reduced $\mathrm{FEV}_{1}$ than other regions.

Differences have been shown in the sensitivity of quantitative measurement parameters. Image analysis is affected by the acquisition parameters, reconstruction technique, slice thickness, respiratory phase and artefacts. In a recent meta-analysis by Crossley et al. (20), 82 studies were examined in which densitometric analyses were applied to COPD patients. In the current study, the images were taken as recommended in the deep inspirium phase and using similar CT acquisition parameters.

Nambu et al. (21) have shown the correlation of parenchyma emphysema severity with $\mathrm{FEV}_{1}$ was evaluated using the \%LAA -950 and \%LAA -910 methods in deep inspirium at $120 \mathrm{kV}$, using a soft tissue reconstruction algorithm. It was determined that \%LAA -910 had a higher correlation coefficient than \%LAA -950. Similar acquisition parameters to those of the current study were used and similar sensitivity of the densitometric methods was determined. Since similar densitometric analysis results are obtained with similar acquisition parameters, standardization of the acquisition parameters of $\mathrm{CT}$ imag- es to be used for densitometric measurements is needed.

In our study, all parameters were found to be at a statistically significantly higher level in GOLD 3-4 than GOLD 1-2. Previous studies in the literature have shown a correlation between GOLD 1234 staging and \%LAA -950, \%LAA -910, MLD, and PD15 parameters (12-25). We also determined that there is a correlation in PD10 methods in addition to these parameters.

Whole lung threshold value was 2.20 for \%LAA -950 (sensitivity $81 \%$, specificity $74 \%$ ). When the GOLD $\mathrm{AB}$ group corresponding to the disease was selected in the analysis of the PD method, the threshold values were -931 HU for PD10 (sensitivity $70 \%$, specificity $70 \%$ ), and $-931 \mathrm{HU}$ for PD15 (sensitivity $82 \%$, specificity $64 \%$ ). In literature, ROC analysis using GOLD ABCD staging and densitometric parameters has not been performed. There are studies in the literature showing a correlation between densitometry and clinical scale scoring and the frequency of attacks $(26,27)$. Independent of the spirometric values, it has been shown that the shift to the left of the histogram curve increases as the severity of clinical findings and the number of attacks increase.

Skewness and kurtosis are frequently used parameters in the quantitative evaluation of interstitial lung diseases, but there are few studies which have used these in the quantitative evaluation of emphysema $(28,29)$. When the correlations between skewness and kurtosis values in nine regions and $\mathrm{FVC}, \mathrm{FEV}_{1}$ and $\mathrm{FVC} / \mathrm{FEV}_{1}$ indicating small airway disease were examined, no significant relationships were found.

Several studies have reported that cigarette smoking shows a strong correlation with the severity of emphysema $(21,30)$. In the current study, there was seen to be a strong correlation with all the quantitative measurement parameters.

A decrease in BMI is expected in emphysema predominant type (31). In the current study, a strong negative correlation was determined between weight and the extent of emphysema in the \%LAA and PD parameters, which was thought to be due to weight loss and falling BMI in patients.

Miniati et al. (32) have evaluated the correlation between height and the extent of emphysema in 727 COPD patients. As height increased so the amount of emphysema increased, and height was suggested as 
a strong independent risk factor for emphysema. In the current study, only high correlation was determined between height and MLD. MLD method provides a mean density of the relevant region. Together with increased height, decreased mean lung density can be observed, but this may not be consistent with the areas of emphysema.

There are some limitations in our study, primarily the retrospective design and low number of patients. There was at least $15 \mathrm{HU}$ between the densitometric threshold values used. A new value may be found showing a higher correlation with the use of threshold values at smaller intervals such as $2 \mathrm{HU}$ or $5 \mathrm{HU}$. QCT analysis depends on the brand and model of the device and software used, acquisition parameters, and image quality, so standardization is needed for the quantitative scoring of emphysema to be objective.

In conclusion, QCT parameters with thoracic CT provide objective results in the determination of measurements of the spread and severity of emphysema. There is a significant correlation between QCT analysis and PFT values. It can be suggested that quantitative analysis can be used to evaluate the severity of emphysema.

Ethical Committee Approval: This study was approved by the Ethical Committee of Afyonkarahisar Health Sciences University, Faculty of Medicine (2020/101).

\section{CONFLICT of INTEREST}

The authors declare that they have no conflict of interest.

\section{AUTHORSHIP CONTRIBUTIONS}

Concept/Design: FK, EA, AB, EG

Analysis/Interpretation: EA, FK, EÖ, AB

Data acqusition: EA, FK, EÖ, EG

Writing: EA, FK, AB

Clinical Revision: EÖ, EG

Final Approval: EÖ, EG

\section{REFERENCES}

1. Weinberger ES. Principles of Pulmonary Medicine. $7^{\text {th }}$ ed. Elsevier, 2017.

2. Fujimoto K, Kitaguchi Y, Kubo K, Honda T. Clinical analysis of chronic obstructive pulmonary disease phenotypes classified using high-resolution computed tomography. Respirology 2006; 11(6): 731-40.
3. Lim JU, Kim EK, Lim SY, Lee JH, Lee JS, Lee SD, et al. Mixed phenotype of emphysema and airway wall thickening is associated with frequent exacerbation in chronic obstructive pulmonary disease patients. Int I Chron Obstruct Pulmon Dis 2019; 14: 3035-42.

4. Camiciottoli G, Orlandi I, Bartolucci M, Meoni E, Nacci F, Diciotti $S$, et al. Lung CT densitometry in systemic sclerosis: correlation with lung function, exercise testing, and quality of life. Chest 2007; 131(3): 672-81.

5. Lynch DA. Progress in Imaging COPD, 2004 2014. Chronic Obstr Pulm Dis 2014; 1(1): 73-82.

6. Parr DG, Dirksen A, Piitulainen E, Deng C, Wencker M, Stockley RA. Exploring the optimum approach to the use of CT densitometry in a randomised placebo-controlled study of augmentation therapy in alpha 1-antitrypsin deficiency. Respir Res 2009; 10(1): 75.

7. Mascalchi M, Camiciottoli G, Diciotti S. Lung densitometry: why, how and when. J Thorac Dis 2017; 9(9): 3319-45.

8. Global Initiative for Chronic Obstructive Lung Disease. Global Strategy for Prevention, Diagnosis, and Management of COPD. www.goldcopd.org (2018).

9. Fedorov A, Beichel R, Kalpathy-Cramer J, Finet J, FillionRobin J-C, Pujol S, et al. 3D Slicer as an Image Computing Platform for the Quantitative Imaging Network. Magnetic Resonance Imaging 2012; 30(9): 1323-41.

10. Bankier AA, De Maertelaer V, Keyzer C, Gevenois PA. Pulmonary emphysema: subjective visual grading versus objective quantification with macroscopic morphometry and thin-section CT densitometry. Radiology 1999; 211(3): 851-8.

11. Gevenois PA, De Vuyst P, de Maertelaer V, Zanen J, Jacobovitz D, Cosio MG, et al. Comparison of computed density and microscopic morphometry in pulmonary emphysema. Am J Respir Crit Care Med 1996; 154(1): 187-92.

12. Müller NL, Staples CA, Miller RR, Abboud RT. "Density mask". An objective method to quantitate emphysema using computed tomography. Chest 1988; 94(4): 782-7.

13. Wang Z, Gu S, Leader JK, Kundu S, Tedrow JR, Sciurba FC, et al. Optimal threshold in CT quantification of emphysema. Eur Radiol 2013; 23(4): 975-84.

14. Stoel BC, Stolk J. Optimization and standardization of lung densitometry in the assessment of pulmonary emphysema. Invest Radiol 2004; 39(11): 681-8.

15. Dirksen A, Dijkman JH, Madsen F, Stoel B, Hutchison DC, Ulrik CS, et al. A randomized clinical trial of alpha(1). antitrypsin augmentation therapy. Am J Respir Crit Care Med 1999; 160(5 Pt 1): 1468-72.

16. Madani A, Zanen J, de Maertelaer V, Gevenois PA. Pulmonary Emphysema: Objective Quantification at Multi-Detector Row CT-Comparison with Macroscopic and Microscopic Morphometry. Radiology 2006; 238(3): 1036-43. 
17. Heremans A, Verschakelen IA, Van fraeyenhoven $L$ Demedts M. Measurement of lung density by means of quantitative CT scanning. A study of correlations with pulmonary function tests. Chest 1992; 102(3): 805-11.

18. Choo JY, Lee KY, Shin C, Kim S, Lee SK, Kang EY, et al. Quantitative Analysis of Lungs and Airways With CT in Subjects With the Chronic Obstructive Pulmonary Disease (COPD) Candidate FAM13A Gene: Case Control Study for CT Quantification in COPD Risk Gene. Journal of Computer Assisted Tomography 2014; 38(4): 597-603.

19. Chae EJ, Seo JB, Song JW, Kim N, Park BW, Lee YK, et al. Slope of emphysema index: an objective descriptor of regional heterogeneity of emphysema and an independent determinant of pulmonary function. AJR Am J Roentgenol 2010; 194(3): W248-55.

20. Crossley D, Renton M, Khan M, Low EV, Turner AM. CT densitometry in emphysema:a systematic review of its clinical utility. Int J Chron Obstruct Pulmon Dis 2018; 13: 547-63.

21. Nambu A, Zach J, Kim SS, Jin G, Schroeder J, Kim YI, et al. Significance of Low-Attenuation Cluster Analysis on Quantitative CT in the Evaluation of Chronic Obstructive Pulmonary Disease. Korean J Radiol 2018; 19(1): 139-46.

22. de Boer E, Nijholt IM, Jansen S, Edens MA, Walen S, van den Berg IWK, et al. Optimization of pulmonary emphysema quantification on $C T$ scans of COPD patients using hybrid iterative and post processing techniques: correlation with pulmonary function tests. Insights Imaging 2019; 10(1): 102.

23. Koo HJ, Lee SM, Seo JB. Prediction of Pulmonary Function in Patients with Chronic Obstructive Pulmonary Disease: Correlation with Quantitative CT Parameters. Korean J Radiol 2019; 20(4): 683-92.

24. Kumar I, Verma A, Jain A, Agarwal SK. Performance of quantitative $C T$ parameters in assessment of disease severity in COPD: A prospective study. Indian I Radiol Imaging 2018; 28(1): 99-106.
25. Shaker SB, Dirksen A, Lo P, Skovgaard LT, de Bruijne $M$, Pedersen $\mathrm{JH}$. Factors influencing the decline in lung density in a Danish lung cancer screening cohort. Eur Respir J 2012; 40(5): 1142-8.

26. Chierakul N, Phanphongsiri S, Chuaychoo B, Muangman $N$, Totanarungroj K. Relationship between emphysema quantification and COPD severity. I Med Assoc Thai 2014; 97(12): 1290-5.

27. Tanabe N, Muro S, Hirai T, Oguma T, Terada K, Marumo $S$, et al. Impact of exacerbations on emphysema progression in chronic obstructive pulmonary disease. Am J Respir Crit Care Med 2011; 183: 1653-9.

28. Yamashiro T, Matsuoka S, Estépar RSJ, Bartholmai BJ, Diaz $A$, Ross JC, et al. Kurtosis and Skewness of Density Histograms on Inspiratory and Expiratory CT Scans in Smokers. COPD: Journal of Chronic Obstructive Pulmonary Disease 2011; 8(1): 13-20.

29. Matsuoka S, Kurihara Y, Yagihashi K, Niimi H, Nakajima Y. Quantifcation of thin - section CT lung attenuation in acute pulmonary embolism: correlations with arterial blood gas levels and CT angiography. Am I Roentgenol 2006; 186(5): 1272-79.

30. Tomita H, Yamashiro T, Matsuoka S, Matsushita S, Nakajima Y. Correlation between heart size and emphysema in patients with chronic obstructive pulmonary disease: CT-based analysis using inspiratory and expiratory scans. Chron Respir Dis 2018; 15(3): 272-8.

31. Ogawa E, Nakano Y, Ohara $T$, Muro $S$, Hirai $T$, Sato $S$, et al. Body mass index in male patients with COPD: correlation with low attenuation areas on CT. Thorax 2009; 64(1):20-5.

32. Miniati M, Bottai M, Pavlickova I, Monti S. Body height as risk factor for emphysema in COPD. Sci Rep 2016; 6: 36896. 